\title{
Compatibility of Private Agroforestry Management and Managing Forest with Community Program in Central Java, Indonesia
}

\author{
Priyono Suryanto ${ }^{1}$, Widiyatno ${ }^{1}$, Sukirno Dwi Asmoro Prianto ${ }^{1}$, Dwiko Budi Permadi ${ }^{1}$, \\ Agus Affianto $^{1} \&$ Adriana $^{1}$ \\ ${ }^{1}$ Faculty of Forestry, Universitas Gadjah Mada, Yogyakarta, Indonesia \\ Correspondence: Priyono Suryanto, Faculty of Forestry, Universitas Gadjah Mada, Yogyakarta, Indonesia. Tel: \\ 62-274-550-542. E-mail: psuryanto@ugm.ac.id
}

Received: June 21, 2012 Accepted: August 1, 2012 Online Published: January 16, 2013

doi:10.5539/jms.v3n1p178 URL: http://dx.doi.org/10.5539/jms.v3n1p178

\begin{abstract}
In the perspective of sustainability, agroforestry is the last resort of natural resource management which synergizes productivity escalation that meets sustainable principles. However, agroforestry management in Indonesia is still trivial and traditional. This research was done to develop compatible agroforestry development schemes as pro poor technology to support prospective and sustainable management.Research was conducted in Sambak village, Kajoran District, Magelang Regency, Central Java Province, Indonesia. Sambak village has been set by the Ministry of Forestry c.q. the Directorate of Land Rehabilitation and Social Forestry as a model or pilot village for national level program of micro watershed area management since 2008. The research was conducted with Agroforestry Diagnosis and Design approach (D \& D) in combination with Rapid Rural Appraisal (RRA). The research has revealed that agroforestry characteristics in homegarden, dry field, and fields are developed in a simple and traditional way. In addition, there is little connectivity between homegarden, dry field agroforestry, dry field and rice field agroforestry as a unit of ownership and state forests that managed through collaborative forest management schemes or Pengelolaan Hutan Bersama Masyarakat (PHBM). Therefore, it is necessary to apply management strategies by developing compatible management between private agroforestry and managed state forests with PHBM scheme. Three approaches can be proposed simultaneously: 1) land units by redesigning agroforestry system, family unit by reconnecting each land unit, and landscape unit as the old growth forests. Three approaches are fully developed with compatible management.
\end{abstract}

Keywords: agroforestry, compatible management, private forests, state forests, PHBM

\section{Introduction}

Agroforestry is a land management practice that lasts for very long time both in the tropics and in other parts of the world (Kumar \& Nair, 2004) but the information about it is still very limited (Kumar, 2006). Agroforestry in its development experienced a serious threat because of urbanization and land-use change and changes in its composition's composer which are more likely to be monocultures (Kumar \& Nair, 2004; Suryanto et al, 2011a). However, agroforestry mandate continues to expand not only producing timber but also improving the ecosystem, which is recently more evident with the existence of global warming as a serious problem. Agroforestry plays an important role in mitigating climate change-carbon absorption capacity-which nowadays receives serious attention from the parties (IPCC, 2000; 2007).

In the perspective of natural resource management sustainability, agroforestry is the last resort of natural resources management which synergizes productivity improvement that meets the principles of sustainability (sustainable management). Agroforestry is also known as the trees outside the forest (FAO, 2006) or as a forest outside the forest or outside the forest conservation because of the presence of trees that provide significant value in maintaining biodiversity.

However, market orientation changes have tent to alter the trees' composition of agroforestry from polyculture to monoculture and this has become a trade off. In one side, this change can increase productivity; on the other hand this leads to biodiversity decline (Suryanto et al., 2011b). Commercialization of Agroforestry becomes a reality in response to the narrowing land area and climate change factors. Agroforestry management construction has been developed such as agroforestry silviculture regime to avoid incompatibility of structure and function around the 
national park (Suryanto et al., 2011b). Agroforestry silviculture regime synergizes traditional, intensive, productive and sustainable management (Suryanto et al., 2012a).

One of the many developed agroforestry practices in Indonesia is the one which is based on Falcataria mollucana (sengon)-coffee combination. This sengon-coffee agroforestry management in Tangsi River upstream watershed, Magelang, Central Java, Indonesia requires considerable attention of the parties. Tree-based agroforestry management of sengon trees focuses only on height growth. Therefore, this agroforestry system is more characterized by a large number of sengon trees (dense), but poor in diameter growth. Rearranging agroforestry management unit (sengon-coffee) can provide a benchmark to agroforest farmers in an effort to improve sengon's diameter growth, thereby shortening harvesting rotation period and also enhancing the productivity of intercropping. This design is expected to be compatible with managing state forest through collaborative forest management or Pengelolaan Hutan Bersama Masyarakat (PHBM).

\section{Methods}

Research site is in the Sambak village, Kajoran District, Magelang Regency, Central Java Province. Since 2008, Sambak village has been set by the Ministry of Forestry c.q. the Directorate of Land Rehabilitation and Social Forestry as a model or pilot village to national level program of micro watershed area management.

The research was conducted by applying Diagnosis and Design Agroforestry approach (D \& D) developed by Raintree (1986) and Nair (1993) which also combined with the Rapid Rural Appraisal (RRA). The diagnosis was done on the documentary agroforestry systems developed up to now. Then, the diagnosis was also done through a brief review on agroforestry practices to find the developing model, cropping systems and technological innovations that are developed.The brief review was done by making transects of homegarden systems, dry field agroforestry, agroforestry fields, rice fields to the state forests. The state forests are which are managed by state forest company (Perum Perhutani) through the collaborative forest management scheme that is called Pengelolaan Hutan Bersama Masyarakat (PHBM) This scheme allows local villagers to cooperate and manage stat forests in such a way that both receive benefit sharing in terms of timber and non timber forest products. The local community collaborates with Perhutani by forming the Lembaga Masyarakat Desa Hutan (LMDH) or Forest Village Community Organization.

On each agroforestry system, plot measurement was done. The design used was based on agroforestry management development efforts focusing on the intensification of the vertical and horizontal space and in a full agroforestry regime (Suryanto et al; 2010; Suryanto et al., 2011a; Suryanto et al., 2012b).

\section{Results}

Based on the information obtained from the transect, agroforestry management development shows the trajectory of land use from residential to homegarden systems, dry field agroforestry, fields agroforestry, rice fields, rivers, rice fields, fields agroforestry, homegarden, dry field agroforestry and pine-mahagony stands in state forests (Figure 1).

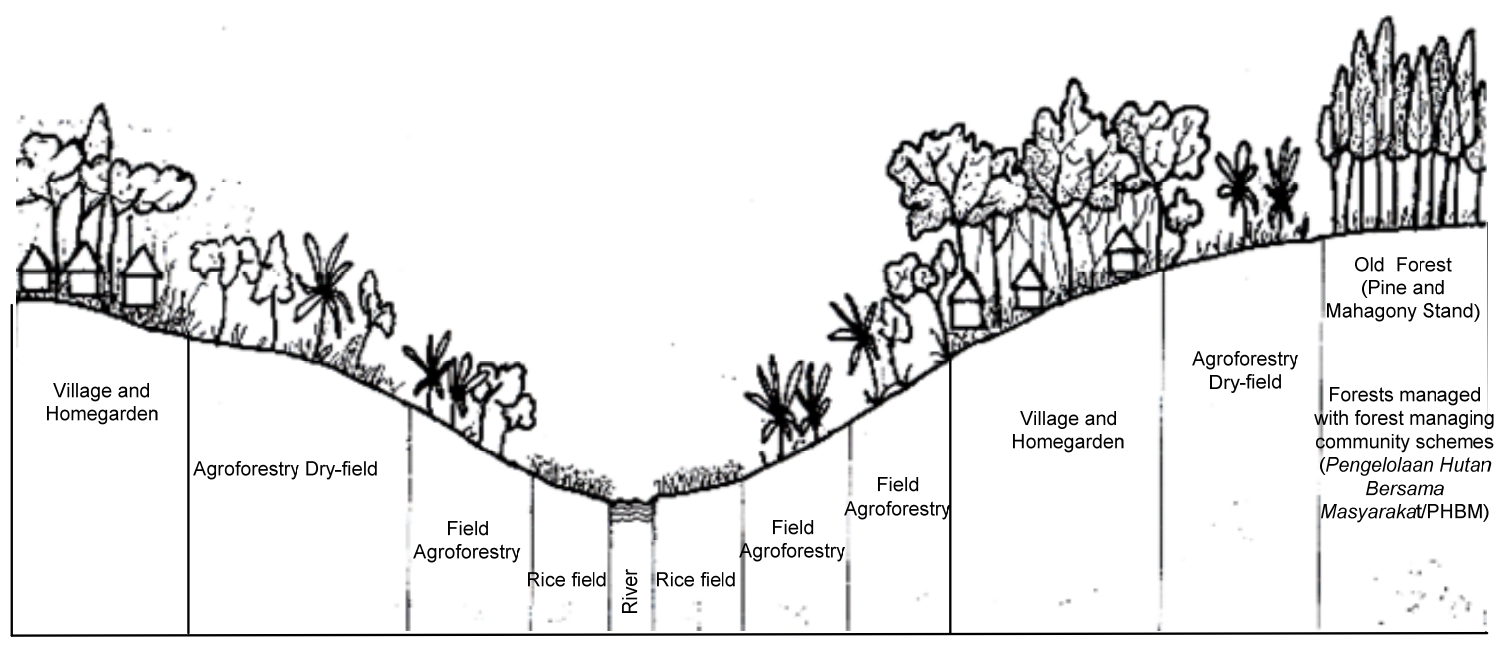

Figure 1. The trajectory of land use from the settlement to the forest in Sambak village 
Characteristics of the agroforestry systems can be seen from the pattern of development which is dominated by mixer and traditional management. In general, developed agroforestry practices have high diversity of species and yields but the number of product produced is low (Table 1). Functions of trajectory of each land unit, that is homegarden aimed for producing food, wood, fruit, coffee, vegetable, fuel wood and others. Dry field agroforestry is similar to the schemes in homegarden. In the fields, agroforestry is more on timber production with the type of fast growing species and grasses, while on the rice field is for paddy production and other crops (Figure 2). However, in relationship with PHBM in state forests, the compatible management level of developed agroforestry is still very low as well as its benefit sharing and responsibility. This occurs because the location of the state forests is far from the residential, and the mahogany and pine forests which are dominated the state forests are entering old ages ( $>50$ years).

Table 1. Agroforestry system characteristics

\begin{tabular}{lllllll}
\hline No & $\begin{array}{l}\text { Agroforestry } \\
\text { system }\end{array}$ & Pattern & Management & $\begin{array}{l}\text { Species } \\
\text { diversity }\end{array}$ & $\begin{array}{l}\text { Yields } \\
\text { diversity }\end{array}$ & Input \\
\hline 1 & Homegarden & Mixer, TAB & Traditional & High & High & Low \\
2 & Agroforestry & TAB, AC, Mixer & $\begin{array}{l}\text { Traditional, } \\
\text { intensive }\end{array}$ & Very high & High & Low \\
& & AC, monoculture & Semi intensive & Low & Low & Average \\
3 & Dry field & Monoculture & Intensive & Very low & Low & High \\
5 & Pine field and & AR & Semi intensive & Two species & Low & Low \\
\hline
\end{tabular}

Note: TAB (trees along border), AC (alley cropping), AR (alternate rows)

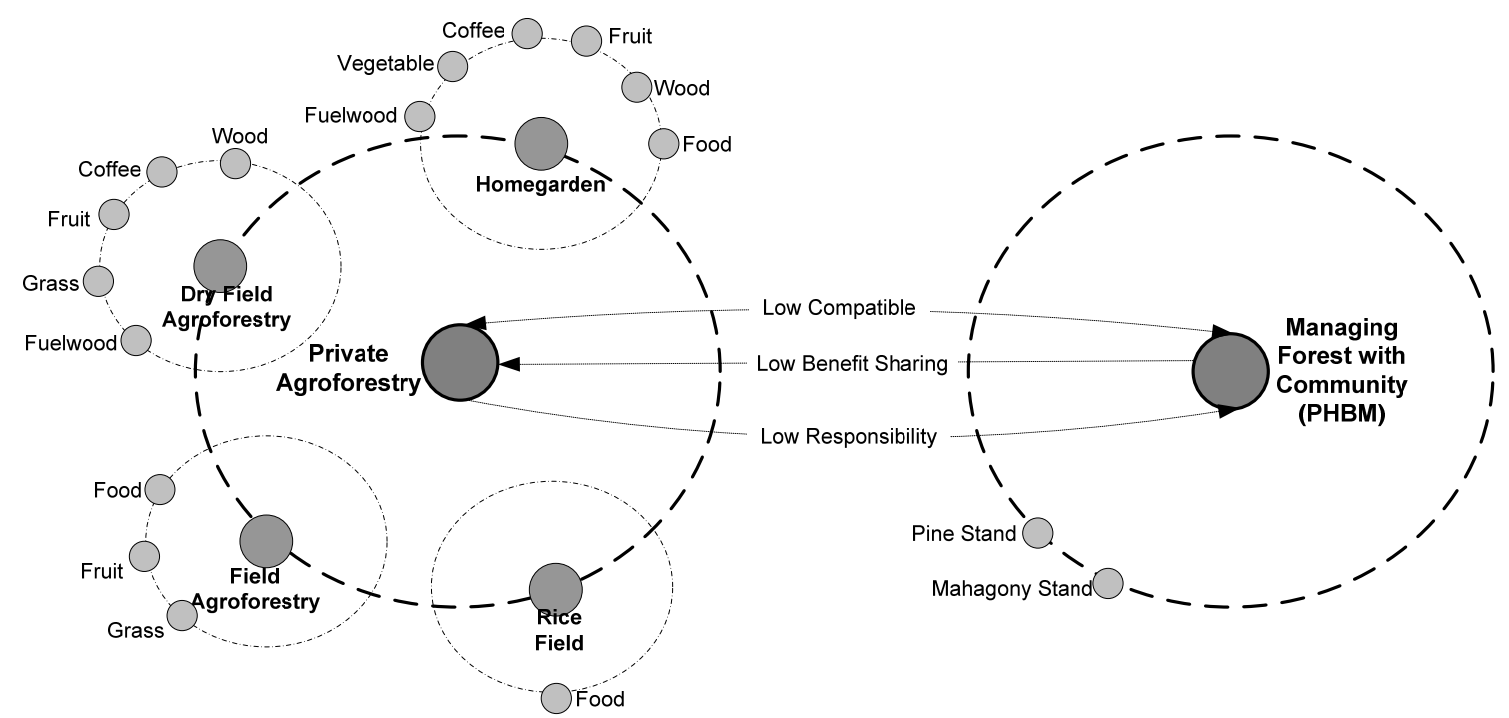

Figure 2. Functional characteristics of private agroforestry and its trajectories in relationship with PHBM in managed state forests by Perhutani

Developing agroforestry techniques shows that the density and biodiversity in an agroforestry unit is high. But the management of agroforestry stands is so low that the product resulted is also low. It also happens to the forests which are dominated by pine and mahogany whose standing stock is limited (Figure 3 ). 


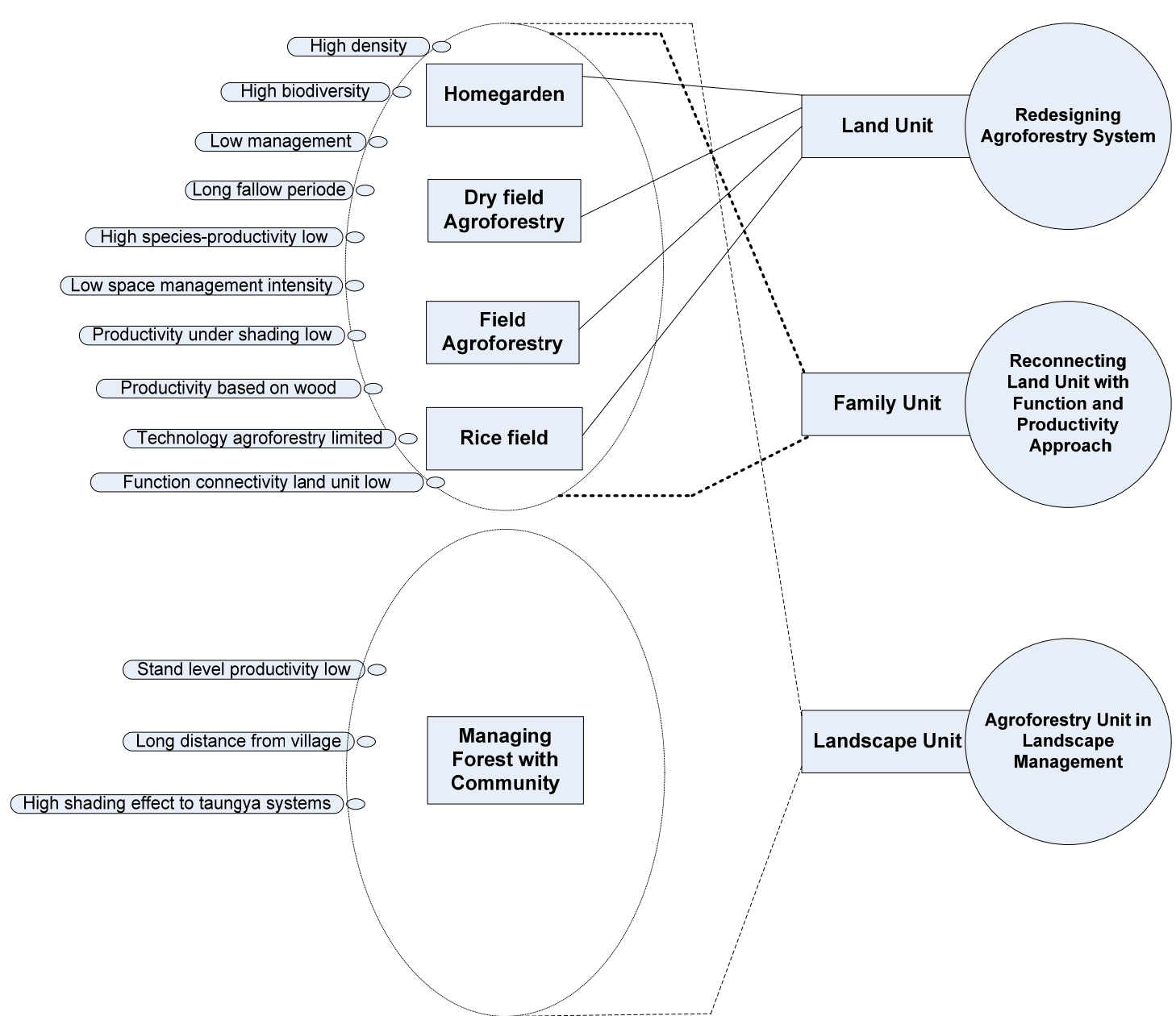

Figure 3. Trajectory characteristics of agroforestry and the scheme of development based on compatible management approaches: from land unit, family unit to landscape unit

Based on these findings, it seems necessary to build agroforestry productivity increase schemes through the holistic management unit by constructing compatibility between land unit and upper level unit, including the state forests. There are three approaches namely land unit by redesigning agroforestry system unit, family unit by reconnecting land unit and landscape unit by including the forest landscape. These three approaches are fully developed with compatible management.

Schemes to increase production capacity at land unit level can be achieved by applying redesigning agroforestry system through intensive sengon-coffee approach. There are three patterns that can be developed for sengon-coffee stand intensification scheme as in Table 2.

Table 2. Existing agroforestry condition and agroforestry technology development strategies

\begin{tabular}{|c|c|c|c|}
\hline Present & Characteristics & Agroforestry technology approaches & \\
\hline Pure Sengon & $\begin{array}{ll}\text { - } & \text { High density } \\
\text { - } & \text { Irregular spacing } \\
\text { - } & \text { Focus on height growth } \\
\text { - } & \text { Small diameter } \\
\text { - } & \text { Under grass'shade }\end{array}$ & $\begin{array}{l}\text { Redesign 1: } \\
\text { Sengon is harvested and replanted with } \\
\text { space arrangement }\end{array}$ & $\begin{array}{l}\text { Redesign 2: } \\
\text { Sengon is thinned (commercial } \\
\text { thinning) and enrichment with } \\
\text { vegetative coffee seedlings }\end{array}$ \\
\hline Sengon-Coffee & $\begin{array}{ll}\text { - } & \text { High density } \\
\text { - } & \text { Irregular spacing } \\
\text { - } & \text { Focus on height growth }\end{array}$ & $\begin{array}{l}\text { Redesign 1: } \\
\text { Non commercial thinning for sengon, and } \\
\text { pruning for coffee }\end{array}$ & $\begin{array}{l}\text { Redesign } 2 \text { : } \\
\text { Commercial thinning for sengon } \\
\text { and the available coffee is grafted }\end{array}$ \\
\hline
\end{tabular}




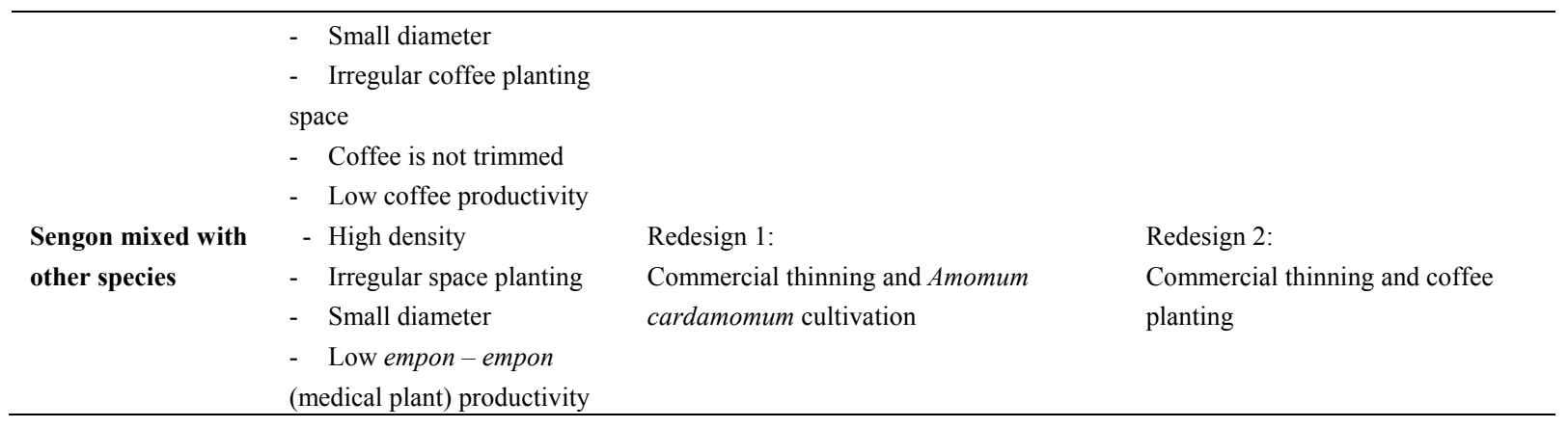

Schemes to increase the land unit connectivity can be done by building compatible management scheme. This approach emphasizes on the species selection setting scheme based on the production function which is compatible with the reduction of unproductive overlapping. Agroforestry practices in homegarden often practice various species cultivation but the productivity is low. In dry field agrofrestry this is also developed to produce vegetables that are in fact the result is low and because of its far distance from house, sometimes harvesting is not done. Rice field unit is focused on food production, thus there is not much overlap with the grass. Based on these considerations it is necessary to do compatible strengthening between one land unit with other in a single ownership. Thus homegarden, dry field agroforestry and rice field as an integrated management unit (Figure 4).

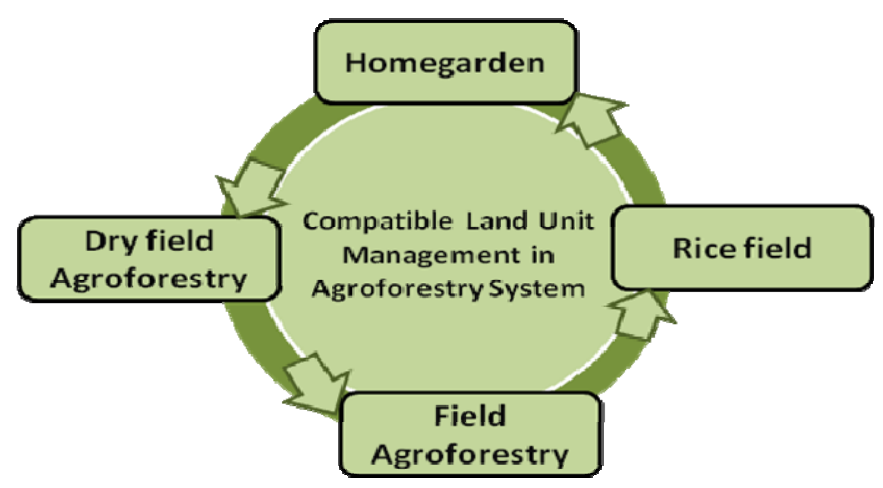

Figure 4. Compatible management scheme on private agroforestry level

Forest management schemes developed by state forest company (Perhutani) with PHBM scheme needs to be integrated with owned land developed with agroforestry. Forests which are located under LMDH become last ecosystem resort until now. This forest existence is very important especially to maintain water system continuity and other environmental functions. Therefore the scheme developed is building compatible management between private agroforestry and managing forest with community. In this scheme private agroforestry is developed with land unit scenario, integrated family unit in landscape unit with the forest. Homegarden intensification encourages its stronger function and productivity including for dry field agroforestry and field agroforestry $(+++)$. Meanwhile, rice field is managed with approach which focuses on sustainable food production. Mahogany and pine stand is managed as old forest $(+++)$ with an important function of maintaining the ecosystem and life sustainability. With this scheme then it will increase the compatible management, benefit sharing and high responsibility (Figure 5). 


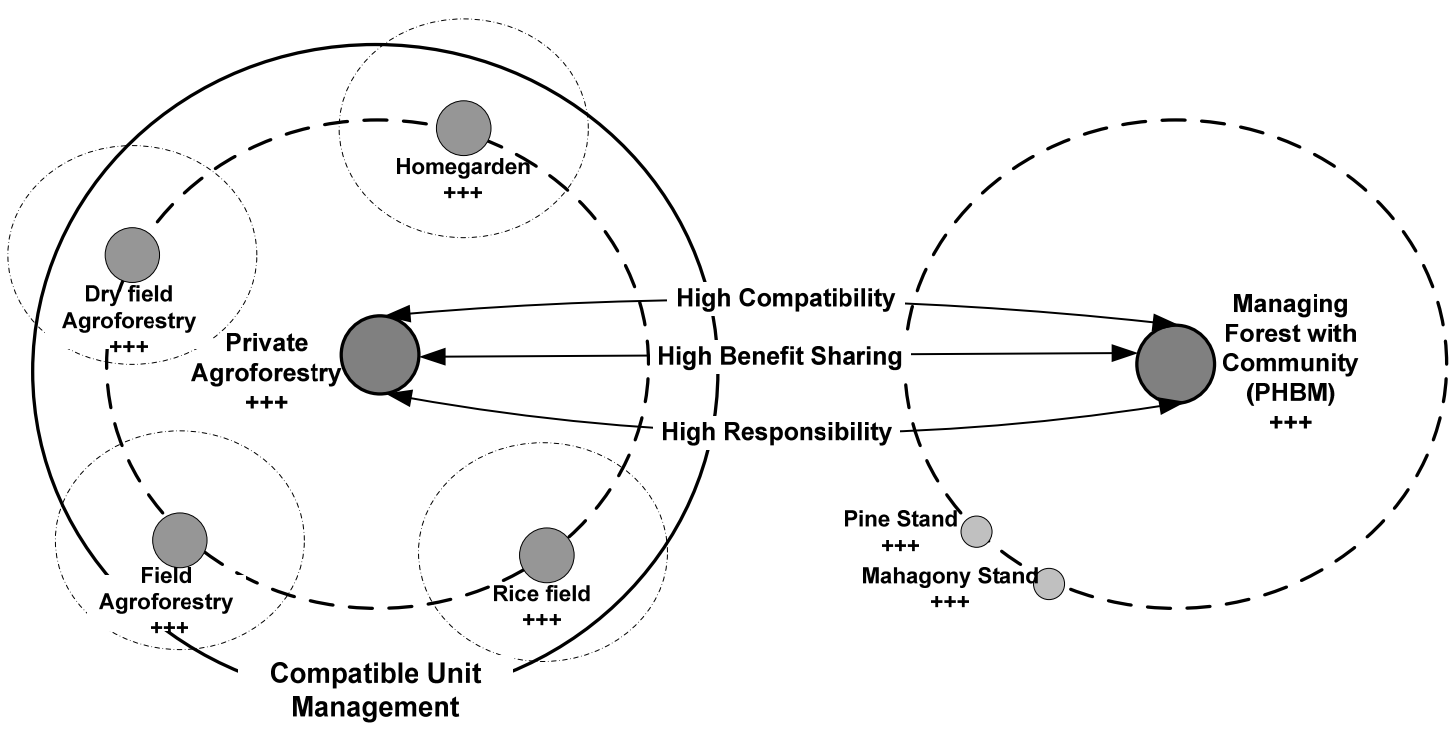

Figure 5. Compatible management of private agroforestry and state forest with community renewal trajectories

\section{Discussion}

Agroforestry which is developed in Sambak village have very important role in local livelihood. Agroforestry offers livelihood benefits (World Bank, 2005). It is as a smallholder tree growing to mitigate the pressure on remaining forest resources and safeguard ecological and socio-economic sustainability (FAO, 2005, 2006). It can be seen from natural resource management practices that combine the components of trees and crops in the same space and time which was running down through the generations. Developed agroforestry systems often provide benefits in the supply of timber, firewood, food, fruits, vegetables and other products. Agroforestry is considered as a functional pattern or related to the farmers' condition. Cluster agroforestry has been done based on structural, functional, socioeconomic, and ecological aspects (Nair, 1993; Ffolliott, 2003). Traditionally, homegarden is mainly characterized with the production of trees, fruits, shrubs, vegetables, medicinal plants and other crops to support staple food crops (Soemarwoto, 1987; Kumar \& Nair, 2004).

Developed agroforestry practices in Sambak village do not vary much with agroforestry in Indonesia in general that is managed in a very simple and traditional way. Developing agroforestry systems can be classified into three kinds; they are initial, intermediate, and advanced agroforestry. Characteristics of each phase of agroforestry are the initial and intermediate agroforestry patterns using trees along border and alley cropping. The stand management in the initial agroforestry is only managed with semi-intensive, while for intermediate and advanced agroforestry, both using conventional approaches (Suryanto et al., 2012a). Assumption developed for agroforester farmers is that more trees means bigger production or its economic value. When in fact the higher trees density then the growth is more focused on height increase thus its tree diameter performance is small (Suryanto \& Putra, 2012).

Agroforestry connectivity based on land units owned by farmers is also small, this can be seen from space setting in resource use and species selection with a high overlapping level but low productivity. Function connectivity of homegarden production, dry field and low fields agroforestry in the context as a single ownership unit by farmers. It is also the same which happened in agroforestry surrounding Mount Merapi National Park (Suryanto et al., 2011a).

Landscape connectivity in landscape level is even lower, this can be seen from the developed community based forest management patterns has not been integrated with agroforestry owned by the community. In 2001 Perhutani, a state owned enterprise with the authority to manage forests in Java, developed a collaborative forest management process with community which is called PHBM. PHBM was an advance on Pembangunan Masyarakat Desa Hutan, or PMDH (Forest Village Community Development program initiated by Perum Perhutani in 1992).

Based on these considerations then it is necessary to formulate compatible management scheme between private agroforestry and forest managed with PHBM scheme. Compatibility occurs when the same forest management is used to produce timber and other resources without contributing to the decline in other sources (Hayness et al., 
2003). There are three approaches to redesigning the land agroforestry system unit, family unit by reconnecting land unit and reconnecting with a compatible landscape management unit. In this context, homegarden and other agroforestry units need to be redesigned to improve connectivity function as a single management unit. Agroforestry practices must be intentional, intensively managed and integrated, either horizontally or vertically, in order to manipulate interactions among the components (Gold et al., 2000). In order to maintain the positive characteristics of homegarden, therefore it is necessary to improve homegarden that counterbalances the on-going trend of homogenization (Kumar \& Nair, 2004). An advantage of this management leads to alternative development paths in adapting to modern agroforestry changing socioeconomic conditions (Peyre et al., 2006).

With agroforestry redesigning with private agroforestry compatible management approach and managed forest with PHBM then it will be a new relationship pattern. Private agroforestry will be more intensive and productive and PHBM forests that function as the old forest will also serve as ecosystem and life security unit. Private agroforestry (community forest management) also plays an effective role in forest conservation (Ellis \& Bolland, 2008). With this fact, the existing agroforestry becomes the key importance especially in maintaining the present biodiversity. Agroforestry de facto controls the poor farmers (Puri \& Nair, 2004), thereby, the configuration agroforestry aids biodiversity conservation (Schroth et al., 2004).

\section{Conclusion}

Characteristics of developed agroforestry in Sambak Village are simple and traditional. Besides, the connectivity of homegarden, dry field agroforestry, field agroforestry and rice field as a single unit of ownership by the farmers is still low as well as forests which are managed by PHBM scheme. Based on these considerations it is necessary to apply management strategy through compatible management among private agroforestry and managed state forest with PHBM. There are three approaches namely land unit by redesigning agroforestry system, family unit by reconnecting land unit, and landscape unit that includes state forests with compatible management.

\section{Acknowledgements}

This research was funded by the Faculty of Forestry Universitas Gadjah Mada (UGM), Yogyakarta, Indonesia through IMHERE program. The author would like to thank the chief of Sambak village, LMDH Chairman and farmers in Sambak village that helped this research. Besides the writer pronounce gratitude profusely to the students involved in this research namely Angga, Rizmon, Jodi, Tazkia, Dea and Lina (student Faculty of Forestry, UGM).

\section{References}

Ellis, E. A., \& Bolland, L. P. (2008). Is community-based forest management more effective than protected areas? A comparison of land use/land cover change in two neighboring study areas of the Central Yucatan Peninsula, Mexico. Forest Ecology and Management, 256, 1971-1983. http://dx.doi.org/10.1016/j.foreco.2008.07.036

Ffolliott, P. F. (2003). Agroforestry-A Primer. Tucson, AZ: School of Renewable Natural Resources, University of Arizona.

Food and Agricultural Organization (FAO). (2005). State of the World's Forests 2005. FAO Rome, Italy.

Food and Agricultural Organization (FAO). (2006). Global Forest Resources Assessment 2005-Progress Toward Sustainable Forest Management. FAO Rome, Italy.

Gold, M. A., Rietveld, W. J., Garrett, H. E., \& Fisher, R. F. (2000). Agroforestry nomenclature, concepts, and practices for the USA. In H. E. Garrett, W. J. Rietveld \& R. F. Fisher (Eds.), North American Agroforestry: an Integrated Science and Practice (pp. 63-76). ASA, Madison,WI.

Hayness, R. W., Monserud, R. A., \& Johnson, A. C. (2003). Compatible forest management: background and context. In R. A. Monserud, R. W. Haynes \& A. C. Johnson (Eds.), Compatible Forest Management (pp. 3-34). Dordrecht, The Nederlands. Kluwer Academic Publishers.

IPCC (Intergovernmental Panel on Climate Change). (2000). Land-use, Land-use Change and Forestry. In R. T. Watson, I. R. Noble, B. Bolin, N. H. Ravindranath, D. J. Verardo \& D. J. Dokken (Eds.), Special report. Cambridge University Press, Cambridge.

IPCC (Intergovernmental Panel on Climate Change). (2007). Climate Change 2007; Mitigation, Contribution of Working Group III to the Fourth Assessment Report of the Intergovernmental Panel on Climate Change. Cambridge University Press, Cambridge, United Kingdom and New York, NY, USA. 
Kumar, B. M. (2006). Carbon sequestration potential of tropical homegardens. In Kumar B. M. \& Nair P. K. R. (Eds.), Tropical homegardens: A time-tested example of sustainable agroforestry (pp. 185-204). Springer Science, Dordrecht.

Kumar, B. M., \& Nair, P. K. R. (2004). The enigma of tropical homegardens. Agroforestry Systems, 61, 135-152. http://dx.doi.org/10.1023/B:AGFO.0000028995.13227.ca

Nair, P. K. R. (1993). An Introduction to Agroforestry. Kluwer Academic Publiser, The Netherlands. http://dx.doi.org/10.1007/978-94-011-1608-4

Peyre, A., Guidal, A., Wiersum, K. F., \& Bongers, F. (2006). Dynamics of homegarden structure and function in Kerala, India. Agroforestry Systems, 66, 101-115. http://dx.doi.org/10.1007/s10457-005-2919-x

Puri, S., \& Nair, P. (2004). Agroforestry research for development in India: 25 years of experiences of a national program. In P. Nair, M. Rao \& L. Buck (Eds.), New Vistas in Agroforestry: A Compendium for the 1st World Congress of Agroforestry. Advances in Agroforestry series (vol. 1). Springer, New York, US.

Raintree, J. B. (1986). An Introduction to Agroforestry Diagnosis and Design. ICRAF. Nairobi, Kenya.

Schroth, G., da Fonseca, G. A. B., Harvey, C. A., Vasconcelos, H. L., Gascon, C., \& Izac, A. M. N. (2004). Introduction: The Role of Agroforestry in Biodiversity Conservation in Tropical Landscapes. In C. A. Harvey, C. Gascon, H. L. Vasconcelos \& A. M. N. Izac (Eds.), Agroforestry and Biodiversity Conservation in Tropical Landscapes, G. Schroth, G.A.B. da Fonseca (pp. 1-12). Island Press.

Soemarwoto, O. (1987). Homegardens: a traditional agroforestry system with a promising future. In Steppler, H. A., \& Nair, P. K. R (Eds.), Agroforestry, a Decade of Development (pp. 157-172). ICRAF, Nairobi, Kenya.

Suryanto, P., \& Putra, E. T. S. (2012). Traditional Enrichment Planting in Agroforestry Marginal Land Gunung Kidul, Java, Indonesia. Journal of Sustainable Development, 5(2), 77-87. http://dx.doi.org/10.5539/jsd.v5n2p77

Suryanto, P., Putra, E. T. S., Suwignyo, B., \& Prianto, S. D. A. (2012a). Silviculture Agroforestry Regime in Community Forestry: Enhancing Compatible Traditional, Intensive, Productive and Sustainable Management. $1^{\text {st }}$ Conference Forest for People, 22-25 May 2012. Tryol, Wienna, Austria.

Suryanto, P., Widyastuti, S. M., Saptohadi, J., Awang, S. A., \& Budi. (2012b). Traditional Knowledge of Homegarden-Dry Field Agroforestry as a Tool for Revitalization Management of Smallholder Land Use in Kulon Progo, Java, Indonesia. International Journal of Biology, 4(2), 173-183. http://dx.doi.org/10.5539/ijb.v4n2p173

Suryanto, P., Zaki, M. H., Azmy, M., \& Azani, M. A. (2010). Agroforestry typology and its implications on surrounding South Region of Gunung Merapi National Park, Java, Indonesia. The Malaysian Forester, 73(2), 229-238.

Suryanto, P., Zaki, M. H., Azmy, M., \& Azani, M. A. (2011a). Silviculture Agroforestry Regime: Compatible Management in Southern Gunung Merapi National Park, Java, Indonesia. International Journal of Biology, 3(2), 115-126. http://dx.doi.org/10.5539/ijb.v3n2p115

Suryanto, P., Zaki, M. H., Azmy, M., \& Azani, M. A. (2011b). Exploring the Potential of Silviculture Agroforestry Regime as a Compatible Management in Southern Gunung Merapi National Park, Java, Indonesia. Journal of Sustainable Development, 4(3), 81-93. http://dx.doi.org/10.5539/jsd.v4n3p81

World Bank. (2005). Agriculture investment note on agroforestry systems. Sustainable Natural Resource Management for Agriculture, Agriculture Investment Sourcebook: Module 5. World Bank, Washington, DC. 